\title{
Uma história da esquerda brasileira a partir de seus livros
}

\section{A history of the Brazilian Left from its books}

\section{Carlos Fernando de Quadros*}

Resenha do livro: SECCO, Lincoln. A batalha dos livros. Formação da esquerda no Brasil. Cotia: Ateliê Editorial, 2017.

Palavras-chave: história da esquerda; história do livro; classe trabalhadora.

Keywords: History of the Left; History of the Book; working class.

O s estudos da história da esquerda e da história do livro no Brasil ganharam nova referência com $A$ batalha dos livros, do historiador Lincoln Secco. Na obra, o suporte material das ideias ocupa a posição de objeto e protagonista histórico. Protagonista, aliás, de uma longa história: das primeiras manifestações em torno do socialismo utópico e de menções rápidas ao nome de Karl Marx e Friedrich Engels até o que de mais recente se publicou reivindicando não só estes, mas também leituras próprias a outras tradições da esquerda, com destaque para o anarquismo e outras manifestações de caráter autonomista.

O livro é composto por cinco capítulos, para além dos textos de prefácio, introdução, conclusão e apêndice, onde são indicadas possibilidades de reflexão e pesquisa para quem queira enveredar-se no mesmo objeto e adjacências históricas. Nesse sentido, as fontes consultadas, discutidas ao final da obra, têm por destaque não só os próprios livros, jornais, revistas e volantes, mas também correspondências entre os militantes brasileiros, desses com diferentes organismos internacionais, catálogos editoriais, inquéritos e prontuários policiais, entrevistas e memórias, registros históricos que são interrogados de diferentes maneiras, como devido. Dão provas do desafio envolvido na reconstituição da trajetória de coletividades sociais cuja existência foi marcada pelo esforço em evitar deixar vestígios de sua ação e pelo de seus antípodas em destruir não apenas a sua existência, mas também a sua memória.

* Mestre em História Social e Doutorando em História Econômica pela Universidade de São Paulo (USP). ORCID: https://orcid.org/0000-0002-3988-5366. E-mail: carlosfquadros@gmail.com. 
Se o título $A$ batalha dos livros já sugere o caráter cruento do processo - da exclusão indireta da classe trabalhadora do debate público à perseguição aberta aos seus representantes políticos -, o subtítulo não é menos indicativo do conteúdo: "Formação da esquerda no Brasil". Trata do "[...] conjunto desses processos educativos [informação, agitação e propaganda], mas seu método é mais lento e se realiza por meio de aula, grupo de estudos, leitura individual ou coletiva de editorial do jornal partidário, manuais e livros marxistas" (p. 192). É a partir de tais processos que o autor realiza uma história da esquerda brasileira, atentando às possibilidades e obstáculos de sua afirmação como sujeito político.

O primeiro capítulo, Primeiras impressões (1830-1919), é relativamente curto tendo em vista a abrangência temporal abordada. É que, conquanto verificadas pelo autor diferentes citações ao socialismo ao longo do século XIX até a formação de núcleos e centros nos primeiros anos da centúria seguinte, nada disso expressa a classe operária com quem se pretendia interlocução. De acordo com Secco: "As iniciativas socialistas brasileiras nasceram dos livros e artigos de jornais e da observação do movimento operário nascente. Raramente do próprio movimento operário" (p. 41). Não obstante, são lançadas luzes a alguns elementos relevantes no período, não apenas para o seu objeto de pesquisa, mas mesmo a processos maiores, conhecidos aqui pelo prisma da totalidade, a partir da articulação com as determinações próprias àquele objeto. Objetivando ilustrar as condições de circulação das ideias no momento abordado, o autor traz importantes dados acerca das condições infraestruturais brasileiras de então, relativas à baixa disponibilidade energética e precariedade das comunicações, por exemplo. Suas considerações sobre o conteúdo concreto do liberalismo e das ideologias que informavam as classes dominantes, a partir da prática política destas, são bastante sugestivas para estudos que porventura venham a extrapolar o objetivo proposto em $A$ batalha dos livros.

No capítulo Sob o Komintern, a atenção é proporcional à relevância do processo de acordo com os propósitos do historiador. No caso, o esforço de difusão do ideário comunista no Brasil, conjugando as iniciativas da militância brasileira com os desígnios da Internacional Comunista, surgida em 1919. A emergência da IC adquire significado especial se estudada pelo seu impacto no Brasil. É que, como demonstrado no capítulo anterior, não havia um movimento operário socialista aqui estabelecido, ao contrário de boa parte dos países vizinhos. É assim que o leninismo é a forma com que o marxismo se estabeleceu no Brasil, determinando que o comunismo preceda o marxismo, sendo o responsável por sua instituição nas ideias e práticas aqui. Comunismo precedente este que é animado por militantes cuja formação política se deu através do anarquismo - então predominante nas hostes radicais da classe trabalhadora brasileira -, forjando-se no ciclo de lutas aberto em 1917. Anarquistas em um esforço de adequação à IC, que necessitam lidar com uma classe trabalhadora afastada dos hábitos de leitura pelas condições estruturais do país.

São acompanhadas aqui as primeiras iniciativas de importação de livros clássicos do marxismo-leninismo em constituição, as traduções que foram necessárias empreender, 
a gestação de interpretações da realidade nacional e de veículos necessários à divulgação das ideias comunistas, como a revista teórica Movimento Comunista (que precede em poucos meses a fundação do PCB) e o jornal A Classe Operária. É uma história acidentada, como de praxe no movimento revolucionário brasileiro, devido à condição clandestina do partido. Chama a atenção o cuidado em evidenciar os limites materiais da empreitada: da aquisição de materiais e estabelecimentos gráficos para a consecução dos referidos projetos ao baixo poder aquisitivo dos interlocutores dos comunistas. Interlocutores esses com quem os dirigentes envolvidos no trabalho de difusão de ideias tinham de desenvolver hábitos de estudo: em uma sociedade majoritariamente ágrafa, a leitura era desenvolvida como uma prática coletiva. São narrados, assim, os variados episódios de um militante ensinando as primeiras letras a outro na prisão ou no sindicato, bem como o fato dos redatores de $A$ Classe Operária indicarem a transcrição de artigos do jornal como uma forma de treino à escrita. Transformações ideológicas de vulto são também abordadas, como a constituição de um vocabulário afinado às terminologias próprias ao movimento comunista que se estabelecia.

O terceiro capítulo, A hegemonia comunista, tem início com a imediata dissolução do Komintern, em 1943. No Brasil, momento importantíssimo na trajetória do movimento comunista, com a reorganização do PCB no bojo dos esforços de União Nacional em tempos de Estado Novo e de guerra mundial. É fundamental para o objeto estudado o desfecho disso, em 1945, quando, em ares de redemocratização, o PCB reconquista brevemente a sua legalidade e adquire expressão de massas. As iniciativas de difusão de ideias ganham nova qualidade. É constituída uma rede de funcionários para atuar em veículos jornalísticos de abrangência nacional e tiragem sem paralelos na esquerda brasileira. As revistas teóricas seguem sendo marca característica da atuação doutrinária dos comunistas, agora acrescidas de textos de autores relevantes no cenário intelectual brasileiro. Uma relação importante não só para o PCB, prestigiado com as assinaturas de Jorge Amado, Graciliano Ramos e Carlos Drummond, mas também para estes hoje consagrados "[...] que se firmam juntamente com o crescimento da influência do partido" (p. 123). Fenômeno relevante este, dado permitir não só dimensionar a relevância do PCB no período, mas indicar uma mirada interpretativa que possibilita matizar a própria constituição de importantes personalidades intelectuais brasileiras. As iniciativas editoriais animadas pelo partido então merecem destaque junto ao esforço formativo promovido nas Escolas de Quadros, abordadas desde o seu planejamento por dirigentes e sua distribuição regional até a espacialidade e cotidiano das mesmas.

A hegemonia compartilhada é o ponto alto de $A$ batalha dos livros. Personagens que outrora tiveram maior destaque, ou compareceram apenas lateralmente, voltam à cena, como os anarquistas e trotskistas. Isso reflete a perda de quase exclusividade do PCB no seio da esquerda que o próprio título do capítulo indica. O Partido Comunista (que, a partir de 1961 torna-se Brasileiro) não perde a sua importância, contudo. Não obstante jamais ter sido livre 
de fato da sanha reacionária, o PCB vivenciou maiores possibilidades de "ação à luz do dia" entre o governo de Juscelino Kubitschek e o golpe de 1964. Eram tempos de reorientação para os comunistas brasileiros: tanto no seio de sua organização, com a substituição de dirigentes, quanto em sua linha política geral, quando assumem objetivos reformistas em sua estratégia, o que implicava em maior aproximação com setores burgueses. Daí o seu maior engajamento em campanhas eleitorais, redundando na ampliação do raio de ouvintes e leitores de sua mensagem. A situação torna-se mais sombria, para as letras e para a esquerda, após o golpe militar.

Atento à gama de novas ideias a circular entre a militância com a crise sofrida pelo PCB e emergência de uma miríade de novas organizações - o autor destaca a Pedagogia do oprimido, de Paulo Freire, como exemplo da "[...] renovação dos modelos da esquerda em relação ao período anterior a 1964" (p. 131), com sua gama de citações de Marx e Engels a Mao Tsé-Tung, Fanon, Kosik e Althusser -, Secco não deixa de evidenciar as dificuldades próprias ao estudo dos escritos da esquerda em uma conjuntura repressiva: mobilizando memórias daqueles que vivenciaram o processo (um recurso fartamente utilizado em todo o seu trabalho), destaca que a aquisição de livros e periódicos críticos tornara-se atividade muito perigosa. A própria produção desses artefatos estava obstaculizada sobremaneira não só com as quedas de quadros, mas com os empastelamentos, apreensões etc. A prisão tornara-se novo lócus de leitura e estudos, com militantes experimentados (como Diógenes de Arruda Câmara e Jacob Gorender) ministrando cursos para os membros jovens da luta armada, e o manuseio de "[...] textos mimeografados, cópias de livros portados com capa falsa" (pp. 134-136). O fôlego da narrativa é renovado, porém, à medida que a classe trabalhadora avançava em suas lutas ao final dos anos 1970 e novos personagens entravam em cena. Essa convergência fica evidente quando o autor discute a literatura lida pelas mulheres operárias e as "leituras da diversidade sexual". Trata-se de uma relação tensa, o que é abordado com a devida sensibilidade. É também sensível e relevante a sua narrativa em torno dos limites dos preconceitos sociais e raciais postos nos diferentes espaços culturais, obstáculo posto ao processo formativo da classe trabalhadora objeto de seu estudo.

Não deixa de ser significativa do novo momento do processo narrado a maior presença de autores antes "fora do cânone" da esquerda, como Rosa Luxemburgo, Trotsky e variados militantes anarquistas, expressando, igualmente, uma maior diversidade editorial na oferta de escritos radicais. Completa o quadro a atenção do historiador aos espaços frequentados pela esquerda leitora de então, fundamentalmente livrarias, os quais reconstitui a partir de entrevistas com atores das mais diferentes regiões brasileiras, evidenciando a diversidade do processo.

O capítulo derradeiro, Autonomia, versa sobre o período aberto em 1989. O Partido dos Trabalhadores, com o segundo lugar na primeira eleição presidencial direta após o fim da ditadura, torna-se hegemônico politicamente entre a esquerda, mas jamais repetiu os 
feitos culturais do PCB. Os opositores à sua esquerda, tampouco. Isto não deixa de refletir perplexidades diante de uma classe trabalhadora que experimenta profundas transformações. Quando o autor discute a sua atuação diante de junho de 2013, em meritório esforço de história do tempo presente, os efeitos disso ficam evidentes (p. 160). Evidentemente que, ainda que a hegemonia cultural da esquerda não estivesse na ordem do dia no período aberto em 1989, os seus escritos não desapareceram. O autor enumera uma série de revistas e de editoras vinculadas a organizações marxistas variadas. $O$ fato de boa parte dessas revistas perderem o vínculo com partidos e abrigarem-se em universidades não é fortuito. É fundamental a constatação em torno de tendências indicadas em momento anterior que se aprofundaram: a atividade editorial de grupos feministas e LGBTs, o vigor editorial de tendências da extrema esquerda (trotskismo, maoísmo, conselhismo e as variadas correntes autonomistas). Junho colocou uma demanda de leitura identificando peculiaridades nessa nova produção de ideias, especialmente no seu suporte, o que não pode ser olvidado: das determinações gerais dos limites da democracia burguesa então em voga, ao próprio fato da baixa nos custos de edição às possibilidades virtuais de driblar a mediação editorial e a crítica especializada da grande imprensa.

Não são só os autonomistas e as coletividades sociais, a quem o discurso de esquerda nem sempre foi devidamente afinado, que emergem na crise da democracia racionada constituída nos anos oitenta: "O mesmo padrão que alimentava o velho anticomunismo retornou no início do século XXI. Sob outras formas" (p. 162). O espaço virtual de difusão de ideias políticas acarretou variadas possibilidades e também variados limites e mesmo obstáculos à classe trabalhadora à qual Secco atenta. Esta é uma realidade posta cuja discussão está longe de terminar.

A particularidade brasileira de sua inserção subordinada e dependente no sistema capitalista, enquanto uma determinação às formas da referida difusão de ideias e sua apropriação, presente em todos os momentos da obra, não pode deixar de atuar na sua conclusão: "A tarefa da esquerda foi assim mais difícil. Ela incorporou temas e discursos europeus, mas enfrentou problemas de diversas idades históricas" (p. 165). A tensão entre dominação e resistência, iluminada aqui a partir de uma história de longa duração das possibilidades e limites de formação e afirmação da classe trabalhadora brasileira, para além de um exercício historiográfico em si digno de nota, não deixa de ser indispensável contribuição em um período no qual mais interrupções parecem ser postas a tal processo, e mais necessário se torna relembrar como, "[...] mesmo caindo, o corredor de cada etapa conseguiu passar a tocha ao companheiro da frente" (p. 166).

Recebido em 23/06/2020

Aprovado em 07/09/2020 